Plenary Session I

Research at the Forefront

of Media Science

\title{
On the Edge
}

\author{
A Meta-Analysis of the State of \\ Media and Communication Research
}

\author{
Klaus Bruhn Jensen
}

In 1983, the Journal of Communication published its now famous theme issue, entitled 'Ferment in the Field,' which took stock of approximately three decades of media and communication studies, and outlined an agenda for further research. One of the contributions summed up a skeptical position in its title: "What Ferment?" (de Sola Pool, 1983). The author, Ithiel de Sola Pool, went further:

I wish there were some ferment, but I fail to find it. Fermentation is a productive process; the enzymes produce a feisty brew. Is current communications research in ferment, or is it at a dead end? Is anything new and productive being done, or are we treading water? My answer is an optimistic one, but more because of what the world is doing to the discipline than because of what is happening within the discipline. (p. 258)

These questions serve as a reminder that, whatever metaphor one chooses, the notion of research in 'ferment,' at 'the forefront,' or on 'the cutting edge' is inherently controversial. The answers, whether optimistic or not, similarly carry theoretical as well as political premises. For example, de Sola Pool assumed that "we" are an established "discipline," rather than the ad hoc "field" referred to in the title of the journal issue. But, is there a 'we'? And, is there even a 'field'? What ferment? What field?

Before one begins to identify singular exemplary studies, let alone entire theories or methodologies that might represent the wave of the next millennium, while assigning others to historical oblivion, I propose to examine some of the premises of such an evaluative enterprise. In the first and main portion of this presentation, I take the opportunity of the conference theme to engage in a meta-analysis of what is 'a cutting edge,' with reference to prototypical examples from previous research. Second, I begin to confront the question of where the cutting edge of media and communication research might be in the future - if the edge and the field both exist.

My own premises for examining those of others, in brief overview, are as follows (see further Jensen, 1995: chaps 9-11). Media and communication researchers established 
themselves initally as two distinctive academic subcultures, recalling C.P. Snow's (1964) sensitizing simplification regarding arts and sciences. Much effort has gone into theoretical and methodological reintegration and 'convergence,' particularly since the time of the 'Ferment in the Field' issue, in order to tap the best of both worlds for the production of more, more valid, and more socially relevant knowledge. The current end result of that complex historical development, at least in the Nordic countries, is a 'field' which is on the verge - on the edge - of becoming a 'discipline.' At the core of the field are the various media technologies, their social institutions and characteristic textual genres, even while countries and universities may cut up the field differently: Is film, for example, one medium among others? Is journalism a privileged area of research and professional training, or one of many genres? In terms of the frameworks that produce scientific continuity - departments, journals, conferences, and consultancy to public and private clients - the field of media and communication research is now a de facto discipline in the Nordic countries, boasting academic presence as well as public legitimacy. The edge is no longer departmental status, nor even convergence of formerly antagonistic traditions within and between departments, although struggles, not least over the conditions of convergence, remain part of the ongoing business of research (e.g., Rosengren, 1996; Jensen, 1996).

In his 'Ferment' article, Ithiel de Sola Pool (1983) had referred to the common distinction between forces which are internal, respectively external, to scientific research, suggesting that he was optimistic because of "what the world is doing to the discipline" (p. 258), rather than vice versa. While I go on to question the distinction between basic and socially relevant research, this distinction provides a familiar frame in which to assess competing conceptions of 'the edge.' In this first part, I critique four earlier interventions, two each from basic and applied perspectives, returning in the second part to a less critical, more reconstructive discussion of where the field might find its next edge.

\section{What Is a Cutting Edge?}

In basic research, a key issue, even the main justification for the existence of the field as such, has been the study of 'effects.' An important resource in this area has been the volume, Milestones in Mass Communication Research, subtitled 'Media Effects' and edited by Lowery and DeFleur, whose title explicitly associates it with the notion of a 'cutting edge.' For my present argument, its most interesting aspects are, first, which 'milestones' have been left out and, next, which milestones were moved along the way of its three editions. From the first to the second edition, from 1983 to 1988, the main, relatively uncontroversial change consisted in the addition of two milestones, namely, agenda-setting research (McCombs \& Shaw, 1972) and the 1982 status report on television and social behavior from the US National Institute of Mental Health (NIMH, 1982). By the end of the second edition, an interesting reference occurred to what the authors called "the meaning paradigm" (Lowery \& DeFleur, 1988: 455). Although their account primarily referred to classical sociology and anthropology, rather than critical and Continental theory, their exploration of 'meaning' in the context of "the social construction of reality" (p. 456) signaled an openness to a variety of theoretical sources and their potential convergence, which was gaining momentum in the 1980s. By the opening of the third edition, however, Lowery and DeFleur had changed their course, with little explanation of what had happened to 'the meaning paradigm': 
It is clear $[\ldots]$ that the dominant mode of inquiry - the major methodology - that has been moving the cutting edge of [the] discipline forward is quantitative research conducted within the theoretical perspectives and methodologies of social science. $[\ldots]$ it is the accumulation of quantitative research completed within the guidelines of the scientific method that has made the most significant contribution to our emerging understanding of the process and effects of masscommunication. (Lowery \& DeFleur, 1995: xi)

This voice, from deep within American mainstream social science, also echoed in the milestones added to the third edition. Besides a belated recognition of early uses-andgratifications research on radio soap opera (Herzog, 1944), the addition was "a relatively obscure study of Iowa corn farmers, and the way they took up a new kind of seed," which arguably led to "a theory of the adoption of innovation" (p. xiii). Whereas this last study might be said to contain seeds of theoretical and methodological innovation, the argument recalls, when seen in the big picture of the past several decades, Jeremy Tunstall's complaint 30 years ago that "too many American studies are about the magazine reading habits of 50 pig farmers in S. W. Iowa" (Tunstall, 1970: 32). A volumelength review of audience research, employing milestone and cutting-edge terminology, and updated from 1983 to 1995, which lacks coverage of any or all of, for example, The 'Nationwide' Audience (Morley, 1980), Reading the Romance (Radway, 1984), or "The Social Uses of Television" (Lull, 1980), is not on, but over the edge.

If the 'milestone' volumes thus are symptomatic of a persistent methodological fundamentalism in their (now self-nominated) dominant paradigm (see also Gitlin, 1978), an equally deep-seated type of limitation has been produced by the theoretical relativism that has been widespread in the other main subculture of media and communication research. A representative position statement from audience studies is Ien Ang's Desperately Seeking the Audience (1991) (see further Jensen,1991a). Like much of the cultural-studies tradition, Ang aligns herself with the position of Michel Foucault. His seminal work is frequently construed to imply that the very production of scientific knowledge is an act of social violence and that, accordingly, the purpose of critical research must be to show that knowledge, as commonly understood, is literally impossible, in the process deconstructing any other position that dares to know anything specific. This politics of research normally involves a moral condemnation of those who exercise power over their 'others' by claiming to know something specific about them. Ang, for one, wanted to rescue television viewers from peoplemeters, a new 'technology of surveillance' in 1991, which she wanted to replace, not complement, by ethnography, because:

[...] 'television audience' is a nonsensical category, for there is only the dispersed, indefinitely proliferating chain of situations in which television audiencehood is practised and experienced - together making up the diffuse and fragmentary social world of actual audiences. (p. 164)

Far from offering the kind of 'concrete' understanding of 'actual' audiences being promised, this position tends to produce a different kind of reification than the dominant paradigm, this time through abstraction. Meaghan Morris (1990) has pinpointed such a self-serving rhetoric that prides itself of its own reflexivity:

[...] people in modern mediatized societies are complex and contradictory, mass cultural texts are complex and contradictory, therefore people using them produce complex and contradictory culture. (pp. 24-25) 
Unless critical researchers are willing to commit themselves also scientifically, by committing virtual violence as they categorize and interpret reality, the likely outcome is an 'endless ethnography' in which the map is as large as the territory - a form of research which has been unable to deliver on its social commitment to counteract real-life violence.

My first two examples, identifying the dual danger of basic research - methodological fundamentalism and theoretical relativism - were drawn from other European and American scholarship, which, to a great extent, has set the agenda for Nordic media and communication research. Beyond the attempt to think globally in its basic studies, the Nordic research community has also acted locally in its applied studies.

Six years ago, the present company had another opportunity, the twentieth anniversary of these Nordic conferences, to take stock of the field through the eyes of younger scholars in dialogue with scholars well-established since 1973. One of the most notable contributions was Frands Mortensen's (1994) personal statement on his itinerary from being a classic intellectual committed to revolution, in part through media research, to being a pragmatic defender of public-service media as the last ditch of social commitment. Apart from being a clear and courageous intervention in itself, his article will be a valuable source when the early history of the field in the Nordic countries is to be written, hopefully before too long. The last few lines of the article, however, could be said to repeat history. Having traced the political and theoretical retreat of 1970 s critical studies, Mortensen now turned his own defensive to an offensive against other, especially younger scholars at the same conference, asking "What is your project?" (p. 48, my translation $\mathrm{KBJ}$ ). My own response, then as now, is that I do not have $a$ project, and I do not think that I should have one, but several projects, depending on where my research orients me, and how it may address the given historical and social context. In my view, the sense of intellectual as well as political retreat stems, in large part, from the momentous miscalculation, now acknowledged by Mortensen and others, of what practical difference critical research might make. I would, additionally, want the procedures of research to be an insulation of sorts from such miscalculations in the future. Although I agree entirely with Frands Mortensen about the value of public-service principles in the current cultural environment, and believe that I, too, can offer evidence to that effect from my own research, I fail to see why this should become the project. History might prove Mortensen wrong once again. Even if the purpose of research is to change, rather than describe, the world, what distinguishes research as a reflexive practice from political practice, is that it allows its practitioners to examine several hypotheses, and to be proven wrong, without resorting to a tragic position, personally or professionally. Two disproven hypotheses may ultimately do more for society than one good cause.

Alongside critical activism, research may hope to make a social difference by institutionalizing its efforts around special issues. A recent example of such efforts is the International Clearinghouse on Children and Violence on the Screen, financed by UNESCO and the Swedish Government, organized by Nordicom, and located at the University of Gothenburg. The implicit premises of the organization appear to be that the impact of media representations of violence on children could hardly be anything but negative and, further, that research can document, and should counteract, such adverse impact. In the words of its director, Ulla Carlsson, the Clearinghouse will inform various user groups about "measures and activities which aim to limit gratuitous violence in the media" (Carlsson, 1998: 10), whatever "gratuitous" might mean. Despite the cautious rhetoric of its newsletter and yearbook, the Clearinghouse taps into the broad social concern about media impact, not least on children, which, in past public 
debate as well as research, has repeatedly swelled into moral panics (Cohen S., 1972). Furthermore, the Clearinghouse constitutes a marked departure from the original role of Nordicom in documenting and disseminating media research and, more recently, media statistics - a role which has deservedly generated international respect, and which may now benefit the Clearinghouse. To me, the shift raises two concerns. First, although the findings are complicated and mixed, some seventy years of research have not, in my assessment, documented more than marginal effects of media violence on the opinions and behavior of audiences, when all is said and done. Second, a further unstated premise of much work in this area is that the impact of media violence on children should be avoided at almost any cost. By contrast, I find it necessary to state that a severe negative impact on, perhaps even the death of, a number of children may be a price to be paid for media, as for other modern technologies, to be weighed against the benefits on several parameters. One twentieth-century parallel is the automobile, whose effect is far from marginal, and unequivocally documented. The fact that cars kill hundreds of people on Nordic roads every year is accepted in practice as a cost of modern living. My aim is not to be cynical about human suffering, whether on public roads or in private homes, but to suggest other dangers in pretending that, if only more research were available, politicians as well as citizens would know which priorities and value judgments to make in this area.

From one perspective, then, the Clearinghouse amounts to a way of thinking too locally, just as the one-project critical activism constituted a mistaken attempt to act globally. Like the theoretical provincialism of the 'milestone' and 'endless ethnography' positions, these political provincialisms are not likely, in my opinion, to bring media and communication research to any edge.

\section{Where Is the Cutting Edge?}

If one can agree that media and communication research is now a de facto discipline, or at least a well-established field, I want to argue, in this second part, that its cutting edge is located neither in specific theoretical debates, nor in socially committed research as traditionally understood. Rather, the cutting edge may be found at the interface of the field with other disciplines, departments, and, to a degree, other social institutions outside the academy. My premises for this argument are as follows, again in brief overview. The field has drawn on a variety of sources from the social sciences as well as the humanities in order to describe, interpret, and explain the main cultural forms of the twentieth century. Indeed, media and communication research can be taken as a characteristic case of how twentieth-century scholarship has frequently turned 'interdisciplinary,' as the terminology goes, to be able to account for new social realities. In this respect at least, all research is applied, and is itself a form of social action that feeds back into media and society, what Giddens (1984) has called the double hermeneutic. Media are hermeneutic vehicles, what I have called institutions-to-think-with (1991b), paralleling Claude Lévi-Strauss' (1962/1991) notion of objects-to-think-with in anthropology. Universities and other research entities are second-order institutions-to-think-with, enabling reflexivity about the nature and purpose of media, among other subjects. What distinguishes the present historical juncture as a particular phase of modernization, is the intensified role of 'information' and 'communication' for the purpose of imagining new realities, both in material production and in politics and culture (Harvey, 1989). It is at this juncture that media and communication research assumes a new position, in- 
side as well as outside academy, and it is a position whose potential has barely been identified, let alone systematized, in the published literature, except perhaps in reference to 'IT' buzzwords.

In the consolidation of the field still to come, the traditional issues of classic scientific quality and social relevance, like those raised by my four prototypical examples, certainly remain important items on the research agenda, to be debated as a matter of course. My brief analysis of the examples was designed to identify some obstacles to consolidation which arise from an insufficient measure of, in one word, professionalism. With respect to scientific quality, the 'milestone' position seemingly remains willfully ignorant of well-publicized theoretical alternatives which do not fit a predetermined methodological matrix. In its turn, the 'endless ethnography' position shies away from conceptual clarity and methodological rigor to the extent that theoretical relativism becomes the logical conclusion: 'You can have your theory, and I'll have mine,' or, worse, 'let's each tell our complex and contradictory story.' With respect to social relevance, the critical vanguard of the 1970s was excused, in part, by its limited professional experience, but a refusal to incorporate past lessons into present research strategies bears witness to a subordination of professionalism as a global requirement to local, provincial commitments, as does the implication of the UNESCO Clearinghouse that research on children and media violence is continuously making significant advances with concrete consequences for policy.

The opportunity for media and communication research, I submit, is to build on past theoretical and methodological progress, as the field begins to question present disciplinary lines in the study of communication and culture generally. Whereas I realize that some colleagues see the very idea of scientific progress as an expression of discursive power, I believe that the field as such has advanced, not only institutionally, but substantially and professionally. To exemplify the state of the field (see further Jensen, forthcoming), since the 1950s, survey methodologies have shown assumptions about massive and direct media effects on opinions to be untenable; since the 1960s, cultural theory has expanded the notion of what 'texts' and 'cultural forms' may legitimately be studied; since the 1980s, qualitative reception studies have redefined the role of textual analysis as a source of hypotheses to be tested empirically; and from the 1990s, cognitive studies of film and other media have begun to undermine the stronghold of psychoanalytic metaphors in studies of audiences as bodies in the flesh (Lakoff \& Johnson, 1999).

The time may be right for translating these contributions into a reconfiguration of the academy. Media and communication research increasingly overlaps with a variety of humanistic and social-scientific subspecialties, not just because of what de Sola Pool (1983) referred to as internal and external factors respectively, but also because the field was a latecomer and, perhaps, a late starter. The natural conclusion to the dramatically revised understanding, since the 1960s, of the phenomena of culture and communication across disciplines from literary theory and linguistics to sociology, anthropology, and geography, to me, is a revision of the institutional frameworks. Accordingly, media and communication research should become neither a field, nor a discipline, nor a department, but a faculty with a number of departments and other constituents. I anticipate much opposition to any such plan for financial, intellectual, as well as biographical reasons, certainly in other departments, but also among bureaucrats and within the field itself. In favor of the realization of this plan counts not only the history that I have retraced summarily, but also a social context in which both the political establishment and the population at large are tending to see culture and communication through the con- 
cepts and terms of this field. Among the benefits of a Faculty of Media, Communication, and Culture could be a more thoroughly modernized approach to the study of human cultures, a more differentiated training of a central, expanding profession, and a reconsideration of what forms of culture and communication should be preserved for the future in museums and archives. The edge of the field, in sum, is its boundaries with other fields and institutions, which are ready to be moved.

\section{Conclusion}

In 1993, the Journal of Communication again took stock of 'The Future of the Field,' ten years after the 'Ferment' issue. By coincidence, all three speakers in this plenary session were among the contributors to two issues of continuing debate about fields and disciplines, scientific quality and social relevance (Jensen, 1993; Livingstone, 1993; Newcomb, 1993). I presume that stock-taking will take place again in 2003, with or without the participation of this panel, and my best guess is that a Faculty of Media, Communication, and Culture will not yet be in place in 2003. Nevertheless, in the longer term, my prognosis is that it can materialize. Compared to the otherwise trendsetting American context, where the outcome has been two separate subdisciplines of interpersonal and mass communications (Rogers, 1999), the Nordic contexts of media research are smaller as well as more homogeneous. In addition, both Europe and the US offer examples of 'schools of communication' with component departments and sections, even though I know of no reconfiguration on the scale imagined here. Moreover, those who remember previous conferences of the present company, and of the IAMCR (International Association for Media and Communication Research), recall that the reference used to be to 'mass communication research.' Now, in the Nordic context beginning with this very conference, we refer to 'media and communication research.' As Raymond Williams (1983) has reminded us, changes in such keywords are indicative of major changes of practice. One background to the new terminology has been the coming of the computer as an intermediary between interpersonal and mass communication, and as a meta-medium integrating previous media on a single platform. Another background to the fall of the 'mass' terminology, paradoxically, has been the consolidation of (mass) media research as a distinctive field which, as noted, has begun taking over the study of culture and communication from established disciplines.

Finally, it seems appropriate to credit the music which has accompanied the first phase of media and communication research. Despite the fact that music remains one of the most underresearched aspects of media, rock 'n' roll has, arguably, inspired new ideas about culture and communication also among the first generations of media and communication researchers. Leonard Cohen (1988) commented a decade ago:

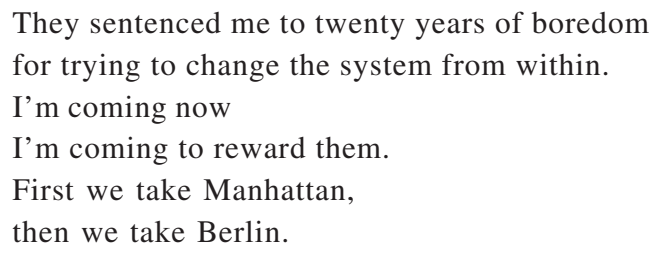

First we took a Department, then we take a Faculty. Ladies and gentlemen, you can be an active audience. Let's 'take Berlin'. 


\section{References}

Ang, I. (1991) Desperately Seeking the Audience. London: Routledge.

Carlsson, U. (1998) "Foreword." In U. Carlsson and C. von Feilitzen (eds.), Children and Media Violence. Gothenburg, Sweden: The UNESCO International Clearinghouse on Children and Violence on the Screen. Cohen, L. (1988) "First We Take Manhattan." I'm Your Man. CBS 4606422.

Cohen, S. (1972) Folk Devils and Moral Panics: The Creation of Mods and Rockers. London: MacGibbon and Kee.

Giddens, A. (1984) The Constitution of Society. Berkeley: University of California Press.

Gitlin, T. (1978) "Media Sociology: The Dominant Paradigm". Theory and Society, 6.

Harvey, D. (1989) The Condition of Postmodernity. Oxford: Basil Blackwell.

Herzog, H. (1944) “What Do We Really Know about Daytime Serial Listeners?”. In P.F. Stanton (ed.), Radio Research 1942-43. New York: Duell, Sloan, and Pearce.

Jensen, K.B. (1991a) “An Unruly Lot: Review of Desperately Seeking the Audience, by Ang." Journal of Communication, 41(1).

Jensen, K.B. (1991b) "When Is Meaning? Communication Theory, Pragmatism, and Mass Media Reception.” In J. Anderson (ed.), Communication Yearbook, 14, Newbury Park, CA: Sage.

Jensen, K.B. (1993) "The Past in the Future: Problems and Potentials of Historical Reception Studies.” Journal of Communication, 43(4).

Jensen, K.B. (1995) The Social Semiotics of Mass Communication. London: Sage.

Jensen, K.B. (1996) “The Empire's Last Stand: Reply to Rosengren.” European Journal of Communication, 11(2).

Jensen, K.B. (ed.) (forthcoming). A Handbook of Media and Communication Research: Qualitative and Quantitative Methodologies. London: Routledge.

Lakoff, G. and Johnson, M. (1999) Philosophy in the Flesh: The Embodied Mind and its Challenge to Western Thought. New York: Basic Books.

Lévi-Strauss, C. (1991) Totemism. London: Merlin Press (Orig.publ. 1962).

Livingstone, S. (1993) "The Rise and Fall of Audience Research: An Old Story with a New Ending." Journal of Communication, 43(4).

Lowery, S. and DeFleur, M. (eds) (1983) Milestones in Mass Communication Research: Media Effects. New York: Longman.

Lowery, S. and DeFleur, M. (eds) (1988) Milestones in Mass Communication Research: Media Effects. 2nd ed. New York: Longman.

Lowery, S. and DeFleur, M. (eds) (1995) Milestones in Mass Communication Research: Media Effects. 3rd ed. New York: Longman.

Lull, J. (1980) "The Social Uses of Television." Human Communication Research, 6.

McCombs, M. and Shaw, D.L. (1972) "The Agenda-Setting Functions of Mass Media." Public Opinion Quarterly, 36.

Morley, D. (1980) The 'Nationwide’ Audience. London: British Film Institute.

Morris, M. (1990) "Banality in Cultural Studies." In P. Mellencamp (ed.), Logics of Television. Bloomington: Indiana University Press.

Mortensen, F. (1994) "Ideologikritik og marxisme: Hvor er medieforskningens kritiske perspektiv fra 70erne blevet af?" [Critique of ideology and Marxism: Where did the critical perspective of media research during the 1970s go?]. Nordicom-Information, 1-2/1994.

NIMH (National Institute of Mental Health) (1982) Television and Behavior. Vols 1-2. Washington, D.C.: Government Printing Office.

Newcomb, H. (1993) “Target Practice: A Batesonian 'Field' Guide for Communication Studies.” Journal of Communication, 43(3).

Radway, J. (1984) Reading the Romance: Women, Patriarchy, and Popular Literature. Chapel Hill: University of North Carolina Press.

Rogers, E.M. (1999) “Anatomy of Two Subdisciplines of Communication Study.” Human Communication Research, 25(4).

Rosengren, K.E. (1996) Review of The Social Semiotics of Mass Communication, by Jensen. European Journal of Communication, 11(1).

Snow, C.P. (1964) The Two Cultures, and A Second Look. Cambridge: Cambridge University Press.

de Sola Pool, I. (1983) "What Ferment? A Challenge for Empirical Research". Journal of Communication, 33(3).

Tunstall, J. (1970) “Introduction.” In J. Tunstall (ed.), Media Sociology. London: Constable.

Williams, R. (1983) Keywords. London: Fontana. 